\title{
IMPACT OF PROMOTIONAL TOOLS ON CONSUMER BUYING BEHAVIOR: A CASE OF FMCG INDUSTRY
}

\begin{abstract}
Ahsan Ali ${ }^{1}$ and Khair Muhammad ${ }^{2}$
ABSTRACT

Instantaneous changes in global socio-economic scenario due to rapid uncertainties and emerging technologies have framed a cutthroat competition between the market players across industries. This colossal change in business structures has altered the consumer demands and driven business focus to search for unique marketing tactics to attract, bring-in, and retain a larger customer pool through various promotional tools. The importance of unique marketing strategies for a business is undeniable as the exclusivity of marketing tools is the core idea to draw customers' attention towards the products. Marketers today are relentlessly trying to decipher new strategies through which changing customer demands could be catered and seek for innovative ideas to attain customer attention. This research project thus intends to test the effect of different promotional tools and their impacts on consumer buying behavior. Every company hence tries to execute various forms of marketing tactics aimed to increase sales and to maximize business market share. Promotion is a mode of marketing that aspires to introduce and at the same time persuade consumers to buy the products offered by the business to enhance the sales volume and increase firm's profit margins. Hence, the purpose of this research study is to examine the impact of different promotion tools which include free samples, product price reductions, free coupons, and buy one get one free offer on consumer buying behavior in FMCG industry in Pakistan. This study has been conducted in Karachi, and a total of 208 respondents was selected using the systematic random sampling technique. The data was collected through the self-administered structured questionnaire which was adopted from previous similar studies. Statistical tools were employed using SPSS and SmartPLS3 software to analyze the
\end{abstract}

\footnotetext{
${ }^{12}$ Students, Benazir Bhutto Shaheed University Karachi
} 
gathered data and find some meaningful results. The significance of this research is extensive as the key findings may help organizations to devise appropriate promotional strategies to minimize their costs and maximize market share as well as profits. Moreover, the practical contributions of this research persist in the identification of sales promotion strategies that are pertinent to the management of clients in the FMCG market in Pakistan. Hence, this study will be beneficial for organizations to minimize their costs related to sales promotion and will provide the right promotional inducement, marketing strategies for business to increase sales by creating purchase behavior practice for display.

Keywords: Sales Promotion; Consumer Buying Behavior; Price Reduction; Free Coupons; Free Samples; Buy One Get One Free Offers.

\section{INTRODUCTION}

Promotional tools have become the most potent instrument for marketers to alter the perception of customers towards a brand and also to stimulate purchase interest. As market competition intensifies, marketers must embrace various strategic techniques to make their products sustainable and also to attract a wider pool of customers. This research will clarify the consumer behavior that is all about individuals, groups, or organizations and all the activities related to the purchase, and disposal of goods and services, and also how the consumer's emotions, attitudes, and preferences affect buying behavior. Now a day, businesses are focusing on various tactics to attract as well as retain customers through several sale promotion strategies like giving a free sample that is a test trial of a product given to consumers in shopping malls, supermarkets, retail stores, or through other channels. Similarly, price reduction or we can say value decrease that is the act of reducing the selling price of merchandise by giving a discount, deduction in the value of something. In other words, we can say the act of decreasing something is also a promotion strategy. Furthermore, by giving coupons to understand coupon is a voucher entitling the holder to a discount off a particular product. In other words, we can say a form in a newspaper or magazine which may be sent as an application to purchase or to inform. Moreover, but not least by giving the offers like buy one, get one free in other words two for the price of one is a common form of promotion strategy. 
The Business environment has gotten to be exceptionally competitive within the 21 st century due to the speed of mechanical alter, framework, and get to access the data around the globe. This has made the environment exceptionally complex and shopper inclinations keep changing since of the low exchanging fetched within the market. Due to this expanding request of consumers within the showcase, the administration of organizations ought to increment their consideration on attracting and holding its customers.

The favorable result of every business is linked and achieved by promotions. Promotions help the business to reach the maturity level of the product and get market fame. Promotional activities are very useful for the business. Promotional activities include sales offering to the customers which affect the behavior of customers while purchasing any desired product. It is the rapid action process to seek customer attention for buying or consuming the new brand product and increasing its sales. It is an activity based on a short process. Sales promotions include the techniques by which consumers get stimulated to give attention to the product. It is not a process of creating long-term affection for the customers as it is provided for a limited period. Sales promotional activity is for capturing more customers and making old loyal customers along with them. Sellers use these promotional tools for boosting profits for small periods. Promotion processes are the chunk of the marketing mix that is used by many promotional tools that increase the gaining large profits.

By using sales promoting tools marketers are widening their business day by day by gaining more profit on the product. As all marketers are using these techniques frequently therefore it has also increased the competition in the market. Moreover, show offing the product on the screens also helps in capturing the new customers.

\section{FMCG - Companies in Pakistan}

\begin{tabular}{l} 
Vegetable Oil Cooking \\
\hline Sweets \& Confectionery Manufacturers \& Suppliers \\
\hline Cookies \& Biscuits Manufacturers \& Suppliers \\
\hline Fruit \& Vegetable Juices \\
\hline Olive Oil \\
\hline Dairy Farming Companies \\
\hline Ice Cream \& Frozen Desserts Manufacturers \& Suppliers \\
\hline Chewing Gum \\
\hline
\end{tabular}




\section{Background \& Industry Brief:}

Today corporations or business organizations spend an extensive amount of the budget on sales promotion activities. The main idea behind offering such promotion activities is to make the goods more enchanting and valuable to the customers. The organization intends to alter consumers' buying behavior and persuasive towards the purchase of the product or service which they are offering. The purpose of this study is to find the impact of various promotional tools on consumer buying behavior although various studies have measured the impact of promotional tools, but the study discusses the impact of free samples, price reduction, coupon, buy one get one free \& consumer buying behavior. We are taking the retail sector (FMCG or other) to conduct the research.

FMCGs we can say, Fast moving customer goods, also called buyer bundled merchandise, are items that are sold rapidly and at a moderately minimal effort. Models incorporate non-tough family merchandise, for example, bundled nourishments, drinks, toiletries, confections, beautifiers (cosmetics), over-the-counter medications, dry products, and different consumables.

\section{RESEARCH STATEMENT}

The purpose of this research is to examine the impact of different promotion tools (free samples, price reduction, coupon, buy one get one free) on consumer buying behavior. The promotional tool's intensity may in turn influence the consumer buying behavior in the FMCG market. Thus, the target of this research is to find out the relation of independent variables free sampling discount with the consumer buying behavior. Do these promotional activities impact the behavior of customers positive or negative?

\section{RESEARCH QUESTIONS}

To meet the research objectives following adaptive research questions were formulated. RQ1: Do the sales promotion tools (coupons, sample, price reduction and buy one get one free) have a significant impact on consumers' buying behavior?

\section{OBJECTIVES OF THE STUDY}

To analyze the impact of different promotional tools on consumer buying behavior which may affect the purchasing behavior of consumers and sales promotion and lead to an increase in sales and business performance. It helps to identify sales promotion tools so companies or organizations can implement that promotional tools. 
To study the reaction of different tools to promote sales on the buying behavior of consumers. Therefore, research on promotional tools is important to understand most of the tools that influence competition with its competitors. Also, the purpose of this is to study closely the taste of the customers in the various promotional tools. With this information, can marketers and retailers plan their resources to gain maximum profit? This study examines the relationship between promotional tools and impulse buying of the product by consumers. Research on promotional tools is important to understand the most powerful tools to compete in the market. Companies then earn a lot of money and expend a hefty cost on promotion but its obvious impact on Consumer purchase is not clear.

\section{SCOPE OF THE STUDY}

With the help of this information, retailers and marketers can make use of their resources to get maximum profit. This research will play a key role for organizations because every organization wants to minimize costs and maximize profits. The practical participations of this research are in identification of sales promotion tactics that are relevant to the management of clients in the first place in Pakistan.

This study is beneficial for organizations to minimize their costs related to promotion tools. This study will provide the right promotional inducement, marketing strategies using business to increase sales by creating purchase behavior practice for display. Thus, organizations must set about to put a lot of money on these tools and situational factors are more attractive.

\section{LITERATURE REVIEW}

\section{Impact of promotions on consumer buying behavior}

By using promotional tools, many products or services can be sold. Manufacturers or retailers give promotions at the store that affect customer preferences and interest to buy it. The buying decision of a person most of the time is the same, but the whole process is not implemented by the customer. It depends on need recognition, information search, alternative evaluation, buying or purchasing decisions, and post purchases (Malombeke, Searang, \& Pangemanan, 2014).

According to Mughal, Mohi-ud-deen, and Ahmed (2014) promotion is a tool, used by the retailer or manufacturer to attract customers and buy more products and services. Increase in sales, high-quality stock, and engaging many new customers somewhere these all depend on promotional strategies. Whenever a customer changes a brand, the reason behind changing his mind could be a great deal to build a smart buyer self-perception. The perfect promotional tool can be a boost to generate more revenue from sales. Similarly, buying behavior is a 
continuously changing and evolving topic. With this fast-changing world, the demands and trends are also changing quickly. New lifestyles have encouraged consumers to try things, adopt new fashions. Despite their low financial capabilities, today's generation looks for new, trendy stuff. That's where markets take advantage by promoting their brands considering the budget of their consumer market, they include various catchy offers to bring new customers to their nets. Purchasing behavior is often ignited by the options available for consumers which vary in price and offer included. Therefore, it's understandable that engaging consumer behavior helps the market to sell more and introduce new products (Ashraf, Rizwan, Iqbal, Khan, 2014).

According to (Malombeke, Searang, Pangemanan, 2014). Consumer buying behavior is very important to understand the customer's behavior. It is important to study the demand of consumers because it helps the selling and convincing the consumers for buying the manufacturer product. Consumer buying behavior is the study of how to make customers buy the product. Marketers recognize the need of the customers.

Similarly, Consumer's buying behavior has been defined and studied deeply and thoroughly in these studies researches it has been identified that there are a lot of factors which can affect consumer buying behavior. The result sure that the promotional tools have a great impact on the consumer buying behaviors for example the blonde changing for choosing time change the quality and brown or also can be switched off. However, it has been seen that consumers purchasing decisions depend on the sensitivity of the price the consumers are always attracted towards promoted products of sales. The four-point which can explain the consumer buying behavior and decisions. Some other factors can be influenced on the customer buying behavior and relations for example cultural and fundamental factors other suicide societal factors and economic factors (Shamout, 2016).

Furthermore, Personal factors are key in framing one's behavior of choice towards the daily routine. These factors can be counted as financial, social, and personal health. Therefore, when the company develops a product, they connect it with the personal behaviors of their potential consumers. Without understanding consumer's social and financial status market may not be able to launch successful products, even if they are launched, their sustainability would be an issue for the market. (Rehman, Yusoff, Zabri, and Ismail, 2017).

Similarly, (Rasool, Mahmood, 2018) indicate that manufacturers or retailers have to know how to deal with buyers to satisfy their needs by understanding the target of each market to increase sales revenue. There are many buyers with different manners and behavior so, the goal of the seller is to satisfy the buyer by need recognition, attracting buyers towards products or services 
which is offered by manufacturers or retailers. Sellers must have to know how to use the perfect strategy to increase sales revenue. The strategy may include free sample offers, free coupons, price reduction, buy one get one free offer, and Communication-behavior. Communicationbehavior needs to be focused on because through communication the seller can be able to inspire the buyer to make a purchase decision. The seller must understand what the customer wants, needs, and demands or convince customers in an effective way to make a purchase decision.

Other studies found that many retailers or manufacturers use promotional tools to attract current and potential customers to buy products and services. The motive of promotional tools is to increase the demand to fulfill needs and create desires to promote goods and services. Promotional tools include free sample offers, free coupon offers, buy one get one free offer, and price reduction offers. The promotional tools help us to understand how different \& multiple customers respond towards products, services which is offered by the market and to understand the impact on Consumer Buying Behavior while making purchasing decisions. By using the perfect strategy, you can increase the sales revenue and get more profit (Imtiaz, Maqsood, Mehmood, and Idrees, 2019).

While other studies found that It is very often said we buy what we demand therefore this notion is developed that better and engaging marketing brings new directions to products. Better marketing and promotion attract new buyers and develop trust among old consumers. With the new developments of technology and new forums marketing agencies have more reach to consumers based on their needs and behaviors achieved by data mining. Therefore, with the revolution of the internet and mobile technology marketing became more focused and specialized according to the consumer personality (Imtiaz, Maqsood, Mehmood, Idrees, 2019). Furthermore, sales promotion is a fundamental marketing tool for manufacturers as well as retailers. Sales promotion is used to increase sales. It is a motivation for customers to buy more. Sales promotion includes free sample offers, free coupons, price reduction and buy one get one free offer also a retailer or manufacturer promote their product or service by using strategic communication method. A retailer must focus on customer reactions while using sales promotional tools. By using sales promotional tools, a retailer or manufacturer can accelerate the purchase level of customers. Sales promotion can stimulate the customer to purchase in terms of behavior responses (Nasir\& Bal, 2020).

\section{Hypothesis - 1: - Sales promotional tools have a significant positive impact on Consumer}

\section{Buying Behavior.}




\section{Frame of mind towards free coupon offers}

The word coupon is associated with those customers who are eligible to acquire vouchers to get an allowance on the product at its usual price. Free coupon offers help to get a price discount on a specific product. Coupons are useful for trial purchase of any product or service. Free coupon offers can be a strong brand switching tool. By giving coupon offers a manufacturer or retailer is promoting their brand, product, or service (Mughal, Mehmood, Mohi-ud-deen, Ahmed, 2014).

Similarly, the word coupon advertisement is related to those customers who get benefit from the products at the original price coupons are defined as priceless on a specific product, for which customers cannot purchase at its original price. Coupons are easily approachable and convenient to understand by the customer and are very useful for trying your product for the first time. (Aurangzeb Mughal, Asif Mehmood, AmmarMohi ud din, Bilal, Ahmed, 2014) According to (Shintia Malombeke, David paul Elia Saerang, Sifrid S Pangemann, 2014). It's a great way to run a storewide promotion on a product, goods, or all the items in which you are doing business. There are some customers which try to purchase less but for next time offer of any good item in your brand. They do not overthink and shop as much as they can because of your coupon benefit. Therefore, coupons are the most beneficial way of marketing your particular product.

Furthermore, free coupon offers can be a package for customers, through free coupon offers a customer can save money on a normal product or service. Manufacturers or retailers provide free coupon offers to give discounts on a specific product or service. By giving free coupon offers customers can take an interest, build trust in a newly launched product or service, free coupon offer is one of the strategic tools of sales promotion that affects purchase decision (Ismail and Siddiqui 2019).

Other studies found that the coupon is applied to those consumers who can get a discount on a normal product. discount in the sense of vouchers, certificates that are used for lower price, products. By going coupons we are reducing the cost and providing brand awareness to make loyal customers. A free coupon is an important tool in advertising activity. The brand must not focus on creating the unsuccessful coupons but also focus on marketing activities .hence through free coupons the customers can attract towards the newly launched product. The product will be more impressive when the customer sees a free coupon offer. The assumption of this study is there is a positive impact of a free coupon on consumer buying behavior. (Imtiaz, Masood, Mehmood, Idrees, 2019). 
Similarly, a coupon is a package for the consumers that provides the benefits to the customers in the sense of saving money. The coupon is offered by manufacturers or retailers which gives discounts to the coupon holders. Nowadays, free coupon offers are the most popular promoting tool in the retailing industry. Retailers and manufacturers found evidence about the faith of customers in free coupon offers and also, they mean customers are taking interest in buying products on free coupon offers. It is one of the strategic tools in promoting activities that mat an effect on a brand in the sense of categorization, choice in the sense of preference, and also it influences behavior. Free coupons are acceptable while making some savings for customers. It very effective while making the purchase decision (Ismail \& Siddiqui 2019).

According to (Samreen, Mashhood, Ali\& Ahmed 2020) A coupon is a transactional tool through coupons the customer can get discounts on purchasing similar products in the future. The reason behind changing manufacturers or retailers one to another is somehow, based on availing coupon offers. Customers have the willingness to change their preferences to avail offers. A free coupon offer is an opportunity for customers to get discounts on selling price through the free coupon offer a manufacturer or retailer communicate to the customers to purchase more newly launched or existing product.

Other studies found that the coupons grant specified savings on selected products. Manufacturers or retailers sponsored coupon offers directly by emailing, dropped door to doors, or distributed through a central location, media-magazine, newspaper, or free-standing inserts (FSI). A free coupon offer is an excellent strategy to stimulate sales, especially in the short term (Abebe, 2020).

\section{Hypothesis - 2: Free coupons have a significant positive impact on Consumer Buying}

\section{Behavior.}

\section{Frame of mind towards Free Sample offers}

A free sample gives acknowledgement about a new product to the market to generate demand. Sample can be small but must be in large quantity to give a great experience of your product to the targeted market you can say samples are the representative of your product. When the demand for products increases then you can stop providing free samples (Danjuma, 2012). According to (Ashraf, Rizwan, Iqbal, Khan, 2014) Free sample offer is a trial package for customers given by the manufacturer or retailer. Before purchasing the customer has the opportunity to try and buy products in near future. Manufacturers or retailers give free sample offers because they want to test direct behavioral experience with a product. The customers can test by themselves rather than just hear about the product. 
Similarly, Free sample is the process of giving samples or trial packets of the manufactured product free of cost to the customers, to attract them and introduce them our product customers use the samples on a trial basis and they are provided or told the advantages and features of the product so that they buy the product in future. free sampling is further used by the traders mostly by the help of providing free samples marketers analyze the value of given merchandise testing and they get the direct behavior experience of customers with the product. according to lanners a free sample have a positive impact on the sales behavior of the product for the product sales. The assumption of this study is there is a dominant relationship between consumer buying behavior and free sampling on product sales according to the above research. (Ashraf, Rizwan, Iqbal, Khan, 2014). Other studies found that When a company produces a new product no one knows that product in the public to introduce that product in the market marketers use different tools of marketing to create knowledge about that product public, free sampling is also one of the most important tools to introduce the newly launched products. In free sampling people get the product by the salesperson to use it and have that sample free of cost samples creates interest in the consumers. The sample is a somewhat small amount of product for consumer testing. Similarly, free samples techniques are to increase our sales. The assumption of this study is free sampling greats a positive relationship with consumer buying behavior. (Ahmed, Mehmood, Ahmed, Mustafa, Khan, Yasmeen, 2015).

Furthermore, the free Sample method is used to induce customers to try newly launched products. It depends on the product's nature and time requirements. The free Sample tool is very effective to stimulate behavior towards purchase decisions, engaging customers to their brand preferences. It helps to increase sales of a promoted product (Shamout, 2016).

\section{Hypothesis - 3: Free samples have a significant positive impact on Consumer Buying Behavior.}

\section{Frame of mind towards Price reduction}

A price reduction Acknowledge the customers to purchase products at a lower price for a specified period. It may also use to take attention away from a competitor. Price reduction offers are used to drive-up short-term sales. price reduction can eliminate the old stock (Danjuma, 2012). 
According to (Ashraf, Rizwan, Iqbal, Khan, 2014) Price reduction is a common tool for offering a good discount that is openly displayed on the product. A customer can take benefit from the price reduction while making a purchase decision. Price reduction is the limited period offers, customers pay attention to price-off promotion while purchasing the product because of the price consciousness of the customer.

Similarly, it is the sales promotional tool in which price is reduced for the customers, it is for a limited period which helps in increasing sales. Fill in 2002 said that price reduction is the well-known tool for offering a discount on the purchasing of the desired product buys the customers. The product test can be gained if the price is cut from the real price of the product. This study assumes that price reduction plays a positive impact on promoting sales. (Ashraf, Rizwan, Iqbal, Khan, 2014).

Similarly, it is very important and commonly used to the promotion of promotion price reduction is applied for a specific period which is displayed on the product while buying the product the consumers are more attention more attracted in price reduced products (Meo, Abbas, Sajjad, Rizwan, Bukhari, and Hameed, 2014).

Furthermore, a reduction describes the discount on the regular selling prices of any good or service, through this method a manufacturer or retailer can attract the consumers and boost the sales. The reduction affects the way customers think and behave while purchasing any product or service. The reduction can be classified into two categories: the first is price discount "on sale items" and the second is a bonus pack on "bulk items". The price reduction contains a certain percentage discount while making the deal, through price reduction a manufacturers or retailers convenience the customer to purchase more products from them. Also, discounts can be classified into two categories the first is "quantity discount" and the second is "seasonal discount" (Abdi, 2015).

\section{Hypothesis - 4: Price reductions have a significant positive impact on Consumer Buying}

\section{Behavior.}

\section{Frame of mind towards Buy one get one free offer (B1G1)}

B1G1 is defined as an extra product is offered at a normal price but with the great improvement in the package to the customer through this, a customer can easily attract towards product or service because there isn't any additional cost for to get double in quantity and this promotion method of sales promotion shall be more valuable by customers, reason the products or services are more convenient to purchase if the customers have the sense of how to save the money 
(Mughal, Mehmood, Mohi-ud-deen, Ahmed, 2014). Similarly, buy one get one is the effective tools used for promotion. It affects the behavior of consumers for buying the product if there is one more or extra product is attached to the men product it influences customers to buy the product buy one get one free call tells favorable effect on consumer buying behavior. Buy one get one is the technique used for sales promotion in which additional products are offered by the manufacturer to the customer to use and creates attention or interest in the consumers. More products are offered at actual prices with more quantity. (Meo, Abbas, Sajjad, Rizwan, Bukhari, Hameed, (2014).

Furthermore, it is the behavior of the consumer to search for something new as it is one of the buying behavior of the consumer. Consumers buy affordable products they search and analyze the wealth factor to buy the product. Buy 1 get 1 offer creates interest in the consumer's mind. This study assumes that it has a positive effect on consumer buying behavior (Ahmed, Mehmood, Ahmed, Mustafa, Khan, Yasmeen, 2015). Other studies found that It is a promotional tool that offers the consumer more on paying a few higher prices. Consumers can comfortably influence the purchase of the product because consumers analyze and understand the value of the additional cost. If the additional value is included in the product by the manufacturer it will make the consumer have attention to it as it will be seen more on paying additional money. The extra quantity of the product encourages people to buy the material as an extra quantity of the material is given by manufacturers. It must be visible to all in the display. This study assumes that it has a positive relationship with consumer buying behavior (Imtiaz, Mehmood, Idrees, 2019). Similarly, B1G1 is one of the sales promotional tools used by manufacturers or retailers to clear the stock and also promote the products at the same time by using exciting packaging to attract customers. Through B1G1 a retailer or manufacturer can instantly grab the attention as the customers are getting double on single item price. (Samreen, Mashhood, Ali, and Ahmed, 2020). Thus, one of the reasons behind the increase in sales can be B1G1 offers.

Hypothesis - 5: B1G1 offers have a significant positive impact on Consumer Buying Behavior.

\section{CONCEPTUAL MODEL}




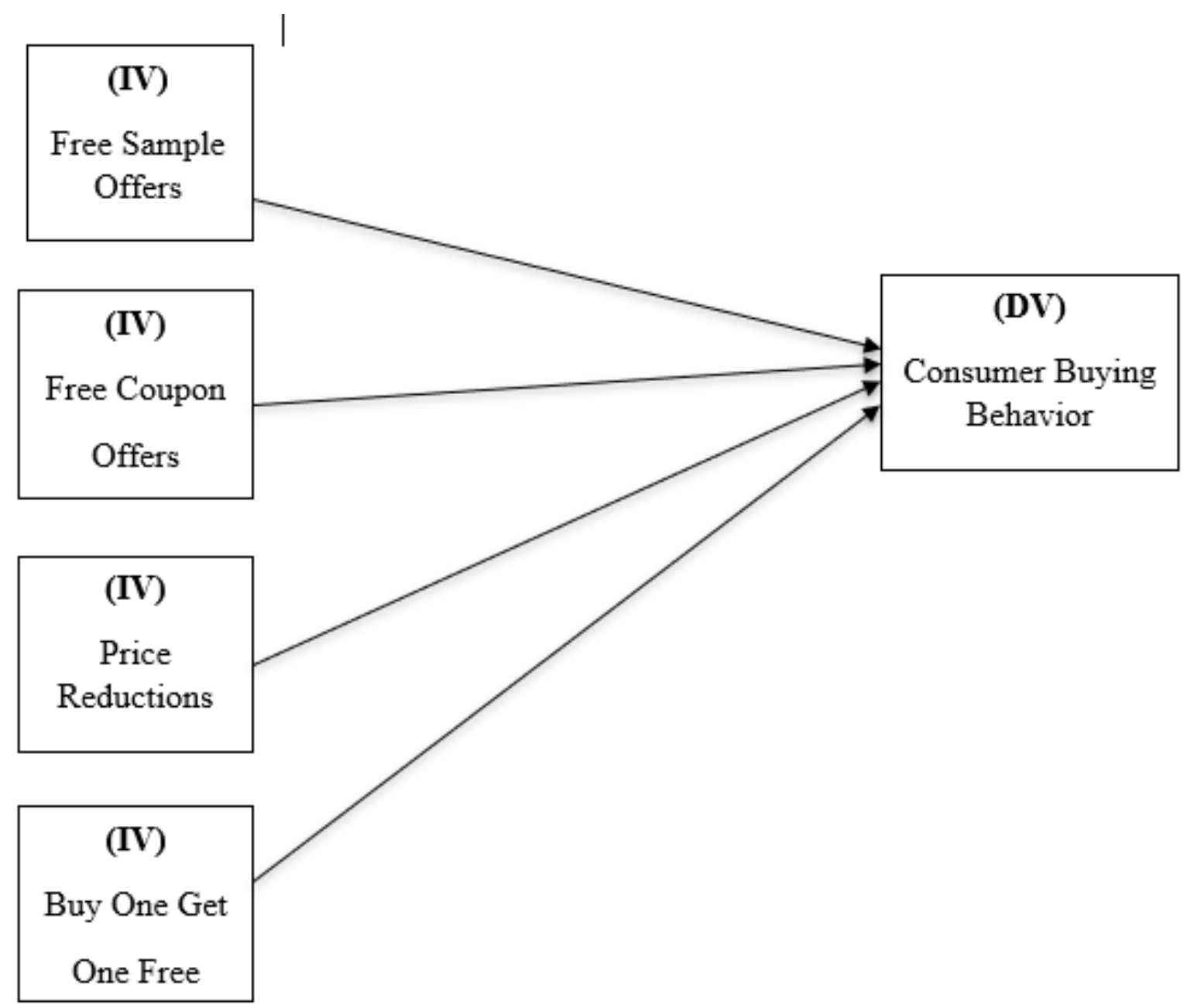

\section{RESEARCH METHODOLOGY}

The data for this study is collected by the questionnaire through online survey (google forms) due to COVID-19 pandemic. The purpose of this research is to study the relationship between different types of promotional tools and consumer buying behavior related to fast-moving consumer goods. The nature of this research is descriptive and follows the quantitative approach to collect the data and based on the literature review test the hypothesis which is developed. Independent variables for this research are "free coupon offers, free sample offers, price reductions, and buy one get one free offer. Also, the dependent variable is consumer buying behavior. The area of the research is at Karachi, Sindh, Pakistan and the research is conducted in year 2020.

\section{Research Design \& Procedure}

The type of study is quantitative and explanatory as we are testing the hypothesis. The scope of this research is applied research because we are conducting this study on users. The research method is mono as it follows a quantitative research approach only. Research technique is 
primarily because the data are taken from customers to know their attitudes towards promotional tools. Furthermore, the study adopts a deductive approach as it is quantitative research and we have taken customers from Pakistan in general. We assume that the results then can also be applied to the other cities. The time horizon is of the study is cross sectionalas the data is taken at one time from different users. A non-contrived natural study setting is followed, whereas the type of investigation is correlational as there is no interference.

This research configuration has been found to give help with the examination of the exploration issue by considering various advantages. The main thought of the blended research configuration is the use of the quantitative just as the subjective plan to give a good comprehension of the issue in the examination (Morse, 2016).

Questionnaire was distributed among two hundred and eight respondents in Sindh, Karachi, Pakistan. The purpose of analysis and also the queries were elaborated to the respondent before sending the form so they'll simply fill the form with relevant responses. For additional analysis these forms were codded and entered into SPSS sheet.

\section{Population}

The size of the population is vast. The population for this research study is based on adults who perform grocery shopping for themselves and others manufacturers, retailers and, marketers. Therefore, all male and female adults above 18 years old is the population of this study. In the geographical area Karachi Sindh, Pakistan. To gain diverse perspective in data to be generated, a diverse group of customers, manufacturers, retailers and marketers is selected.

\section{Sample Size}

The sample size of this study is about 208 respondents as the population is vast, which are asked to participate in the online survey (google form) study in order to gather the primary data for understanding the impact of promotional tools on consumer buying behavior. The people for the current research are manufacturers, retailers, marketers and customers who have experience in buying fast-moving consumer products. The confidence level of this research taken as $95 \%$ and the confidence interval 5 .

\section{Sampling Technique}

The sampling technique is the non - probabilistic technique, used in current research. It uses a convenient sampling technique because in this sampling process information can be collected from the related sample or the unit of the study that is easily available. Convenience sampling is used to collect a large number of questionnaires quickly and at a low cost. 


\section{Instrumentation}

The questionnaire survey is selected as the instrument of the research. The research questionnaire is developed primarily on five variables. Also, other demographic questions such as; age, gender, income and qualification is also listed in the questionnaire to get the better results. The questions are close ended based on Likert scales also, ranging from strongly agree to strongly disagree .Variables of this study are quantitative in nature. There are Free Sample offers, Price reductions, Free Coupon offers, buy one get one free offer independent variable in our research. The dependent variable is consumer buying behavior. There are no subdimensions of variables, so it is a uni-Dimensional study.

\section{RESEARCH HYPOTHESIS}

H-1. Free Coupon offers have a significant positive impact on Consumer Buying Behavior.

H-2. Price Discounts have a significant positive impact on Consumer Buying Behavior,

H-3. Free Sample offers have a significant positive impact on Consumer Buying Behavior,

H-4. Buy One Get One Free offer has a significant positive impact on Consumer Buying Behavior.

\section{DATA ANALYSIS}

The purpose of this study is to find the relationship between consumer buying behavior and different promotional tools. The structured questionnaires are distributed among 208 people in Karachi, Sindh, Pakistan and, the questionnaire is required to collect the primary data. The data is analyzed through SPSS-20 software, Smart PLS-SEM descriptive analysis factor analysis and through Microsoft Excel 365 version. The research approach is explanatory because we are conducting the research on current scenario.

\section{Demographics}

Respondent's profile

\begin{tabular}{|l|l|c|l|l|}
\hline Factors & Respondents & Category & Frequency & Percentage \% \\
\hline Gender & 208 & $\begin{array}{r}\text { Male } \\
\text { - Female }\end{array}$ & $\begin{array}{l}\mathrm{M}-149 \\
\mathrm{~F}-59\end{array}$ & $\begin{array}{l}\text { Male }=71.6 \% \\
\text { Female }=28.4 \%\end{array}$ \\
\hline
\end{tabular}




\begin{tabular}{|c|c|c|c|c|}
\hline Age & 208 & $\begin{array}{l}\cdot \quad 18-25 \\
\cdot \quad 26-35: \\
\cdot \quad 35-45 \\
\cdot \quad 46-55 \\
\text { - } 56 \text { Above }\end{array}$ & $\begin{array}{l}18-25=192 \\
26-35=12 \\
36-45=3 \\
46-55=1 \\
56 \text { Above }=0\end{array}$ & $\begin{array}{l}18-25=92.3 \% \\
26-35=5.8 \% \\
36-45=1.4 \% \\
46-55=0.5 \% \\
56 \text { Above }=0 \%\end{array}$ \\
\hline Qualification & 208 & $\begin{array}{ll}\text { - } & \text { Primary/Mid } \\
& \text { dle School } \\
\text { - } & \text { Metric/O- } \\
& \text { Levels } \\
\text { - } & \text { Intermediate/ } \\
& \text { A-Levels } \\
\text { - } & \text { Bachelors } \\
\text { - } & \text { Masters } \\
\text { - } & \text { Doctorate } \\
& \text { (PhD.) }\end{array}$ & $\begin{array}{l}\text { Primary/Middl } \\
\text { e School = } 1 \\
\text { Metric/O- } \\
\text { Levels = 1 } \\
\text { Intermediate/A } \\
\text {-Levels = 47 } \\
\text { Bachelors = } \\
144 \\
\text { Masters = } 15 \\
\text { Doctorate } \\
\text { (PhD.) }=0\end{array}$ & $\begin{array}{l}\text { Primary/Middle } \\
\text { School =0.5\% } \\
\text { Metric/O-Levels } \\
=0.5 \% \\
\text { Intermediate/A- } \\
\text { Levels = 22.6\% } \\
\text { Bachelors } \\
69.2 \% \\
\text { Masters =7.2\% } \\
\text { Doctorate (PhD.) } \\
=0 \%\end{array}$ \\
\hline Income & 208 & $\begin{array}{llr}\cdot & \text { Below } & 15000 \\
\cdot & 15000 & - \\
& 30000 & \\
\cdot & 30000 & - \\
& 50000 & \\
- & 50000 & - \\
& 80000 & \\
- & 80000 \text { Above }\end{array}$ & $\begin{array}{l}\begin{array}{l}\text { Below } \\
=199\end{array} \\
15000-30000 \\
=51 \\
30000-50000 \\
=24 \\
50000-80000 \\
=9 \\
80000 \quad \text { Above } \\
=5\end{array}$ & $\begin{array}{l}\text { Below } \\
=57.2 \% \\
15000-30000 \\
=24.5 \% \\
30000-50000 \\
=11.5 \% \\
50000-80000 \\
=4.3 \% \\
80000 \text { Above = } \\
2.4 \%\end{array}$ \\
\hline
\end{tabular}




\section{Instrument Reliability}

Construct Reliability and Validity

\begin{tabular}{|l|l|l|l|l|}
\hline & $\begin{array}{l}\text { Cronbach's } \\
\text { Alpha }\end{array}$ & rho_A & $\begin{array}{l}\text { Composite } \\
\text { Reliability }\end{array}$ & $\begin{array}{l}\text { Average Variance Extracted } \\
\text { (AVE) }\end{array}$ \\
\hline B1G1F & 0.775 & 0.530 & 0.718 & 0.570 \\
\hline $\begin{array}{l}\text { Consumer Buying } \\
\text { Behaviour }\end{array}$ & 0.782 & 0.507 & 0.716 & 0.593 \\
\hline Free Coupons & 0.761 & 0.461 & 0.735 & 0.581 \\
\hline Free Samples & 0.744 & 0.527 & 0.714 & 0.539 \\
\hline Price Reduction & 0.618 & 0.304 & 0.646 & 0.574 \\
\hline
\end{tabular}

Table 3. Reliability

\section{Reliability Analyses}

Cronbach's alpha' value and composite reliability for all variables in this study are the acceptable range because more than 0.7 Cronbach's Alpha and composite reliability can be acceptable. And also, the average variance extracted (AVE)'s value is acceptable because the significant value of AVE is 0.5 and the results of the research is above than 0.5 and it can be acceptable as the table shows above.

\section{Validity}

\section{Discriminant Validity}

\begin{tabular}{|l|l|l|l|l|l|}
\hline Discriminant Validity & & & & \\
\hline $\begin{array}{l}\text { Fornell-Larcker } \\
\text { Criterion }\end{array}$ & B1G1F & $\begin{array}{l}\text { Consumer Buying } \\
\text { Behaviour }\end{array}$ & $\begin{array}{l}\text { Free } \\
\text { Coupons }\end{array}$ & $\begin{array}{l}\text { Free } \\
\text { Samples }\end{array}$ & $\begin{array}{l}\text { Price } \\
\text { Reduction }\end{array}$ \\
\hline B1G1F & 0.685 & & & & \\
\hline $\begin{array}{l}\text { Consumer Buying } \\
\text { Behaviour }\end{array}$ & 0.597 & 0.627 & & & \\
\hline Free Coupons & 0.596 & 0.585 & 0.694 & & \\
\hline Free Samples & 0.546 & 0.540 & 0.558 & 0.582 & \\
\hline Price Reduction & 0.512 & 0.506 & 0.510 & 0.541 & 0.523 \\
\hline
\end{tabular}

Table 4. Validity 
Heterotrait-Monotrait Ratio (HTMT)

\begin{tabular}{|c|c|c|c|c|c|}
\hline & B1G1F & $\begin{array}{l}\text { Consumer } \\
\text { buying } \\
\text { Behavior }\end{array}$ & $\begin{array}{l}\text { Free Coupon } \\
\text { Offers }\end{array}$ & $\begin{array}{l}\text { Free Sample } \\
\text { Offers }\end{array}$ & $\begin{array}{l}\text { Price } \\
\text { Reductions }\end{array}$ \\
\hline \multicolumn{6}{|l|}{ B1G1F } \\
\hline $\begin{array}{l}\text { Consumer } \\
\text { Buying } \\
\text { Behavior }\end{array}$ & 0.579 & & & & \\
\hline $\begin{array}{l}\text { Free Coupon } \\
\text { Offers }\end{array}$ & 0.883 & 0.582 & & & \\
\hline $\begin{array}{l}\text { Free sample } \\
\text { Offers }\end{array}$ & 0.717 & 0.593 & 0.738 & & \\
\hline $\begin{array}{l}\text { Price } \\
\text { Reductions }\end{array}$ & 0.700 & 0.586 & 0.844 & 0.701 & \\
\hline
\end{tabular}

Table 5

It is the new method for obtaining discriminant validity in partial least squares structural equation modelling, which is one of the key building blocks of model assessment. If the HTMT value is below 0.90 , discriminant validity has been accepted between two reflective items.

\section{Construct Validity}

\begin{tabular}{|l|l|l|l|l|l|}
\hline $\begin{array}{l}\text { Cross } \\
\text { Loadings }\end{array}$ & B1G1F & $\begin{array}{c}\text { Consumer Buying } \\
\text { Behaviour }\end{array}$ & $\begin{array}{l}\text { Free } \\
\text { Coupons }\end{array}$ & $\begin{array}{l}\text { Free } \\
\text { Samples }\end{array}$ & $\begin{array}{l}\text { Price } \\
\text { Reduction }\end{array}$ \\
\hline B1G1-1 & 0.670 & 0.684 & 0.645 & 0.626 & 0.634 \\
\hline B1G1-2 & 0.839 & 0.678 & 0.670 & 0.668 & 0.674 \\
\hline B1G1-4 & 0.605 & 0.600 & 0.643 & 0.645 & 0.660 \\
\hline CBB1 & 0.603 & 0.457 & 0.696 & 0.631 & 0.657 \\
\hline CBB2 & 0.627 & 0.749 & 0.684 & 0.673 & 0.630 \\
\hline CBB3 & 0.688 & 0.628 & 0.652 & 0.601 & 0.636 \\
\hline CBB4 & 0.638 & 0.637 & 0.657 & 0.223 & 0.600 \\
\hline FCO2 & 0.665 & 0.684 & 0.686 & 0.668 & 0.622 \\
\hline FCO3 & 0.610 & 0.601 & 0.680 & 0.656 & 0.609 \\
\hline FCO4 & 0.665 & 0.607 & 0.714 & 0.623 & 0.624 \\
\hline FSO1 & 0.689 & 0.605 & 0.617 & 0.656 & 0.606 \\
\hline FSO2 & 0.695 & 0.670 & 0.650 & 0.601 & 0.677 \\
\hline FSO3 & 0.680 & 0.618 & 0.631 & 0.641 & 0.668 \\
\hline FSO4 & 0.604 & 0.624 & 0.668 & 0.644 & 0.643 \\
\hline FSO5 & 0.677 & 0.676 & 0.633 & 0.632 & 0.615 \\
\hline PR1 & 0.619 & 0.622 & 0.605 & 0.671 & 0.638 \\
\hline PR2 & 0.667 & 0.683 & 0.664 & 0.624 & 0.613 \\
\hline PR3 & 0.611 & 0.677 & 0.678 & 0.603 & 0.696 \\
\hline PR4 & 0.673 & 0.646 & 0.643 & 0.684 & 0.697 \\
\hline PR6 & 0.650 & 0.648 & 0.663 & 0.690 & 0.631 \\
\hline Tab1e 6 & & & & & \\
\hline
\end{tabular}

Table 6 
The degree to which inferences can permissibly be made from the items in study to the theoretical constructs on which those items are based.

\section{Convergent Validity}

Basically, it mentions to how closely the scale is related to other variables and other computes of the same construct. Not only should the construct correlate with related variables but it should not correlate with diverse, separated ones. Convergent validity focuses on Average variance extracted (AVE) and previous studies tell the value of AVE more than 0.5 considered as reliable and acceptable.

\section{Regression Model:}

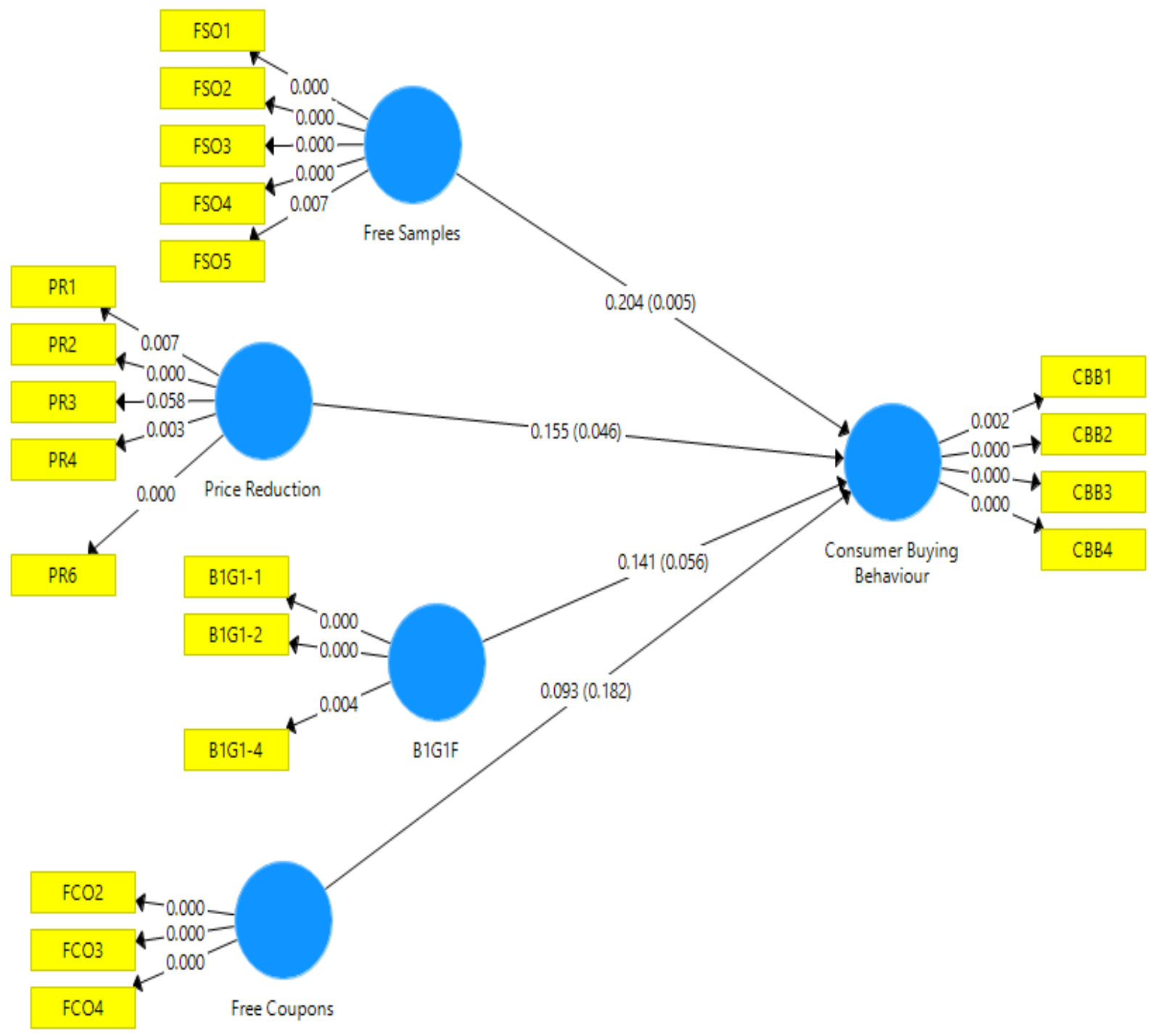




\section{Path Coefficients}

\begin{tabular}{|c|c|c|c|c|c|}
\hline $\begin{array}{l}\text { Mean, STDEV, } \\
\text { Values, }\end{array}$ & & & & & \\
\hline & $\begin{array}{l}\text { Original } \\
\text { Sample } \\
\text { (O) }\end{array}$ & $\begin{array}{l}\text { Sample } \\
\text { Mean } \\
\text { (M) }\end{array}$ & $\begin{array}{l}\text { Standard } \\
\text { Deviation } \\
\text { (STDEV) }\end{array}$ & $\begin{array}{lr}\text { T } & \text { Statistics } \\
(|\mathrm{O} / \mathrm{STDEV}|)\end{array}$ & $\begin{array}{l}\mathrm{P} \\
\text { Values }\end{array}$ \\
\hline $\begin{array}{l}\text { B1G1F } \rightarrow \text { Consumer } \\
\text { Buying Behaviour }\end{array}$ & 0.141 & 0.148 & 0.074 & 1.913 & 0.756 \\
\hline $\begin{array}{l}\text { Free Coupons } \quad \text { >> } \\
\text { Consumer } \\
\text { Behaviour }\end{array}$ & 0.093 & 0.098 & 0.070 & 1.336 & 0.782 \\
\hline 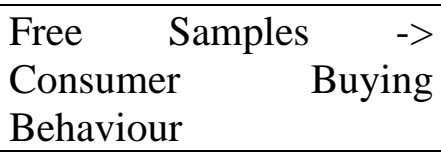 & 0.204 & 0.225 & 0.073 & 2.789 & 0.005 \\
\hline 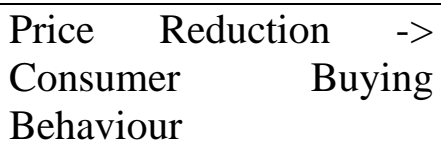 & 0.155 & 0.182 & 0.078 & 1.992 & 0.046 \\
\hline
\end{tabular}

Table 8

We eliminated some of the items like FCO1, B1G1-3, PR5, PR7 and ultimately when these items are eliminated than we found construct the reliable value therefore we use them for further studies. The reliability is appropriate according to the cut off values and the results are shown in above the diagram. In our studies we found two positive impacts of independent variables (free sample offers and price reductions) and other two unlikeable impacts of independent variable (B1G1 offers and free coupon offers) hence, the p-value of B1G1 and free coupon offers are greater than 0.05 which is insignificant and unacceptable and the p-value of free sample offers and price reduction are less than 00.05 which is significant and acceptable.

R Square

\begin{tabular}{l|l|l}
\hline & R Square & R Square Adjusted \\
\hline Consumer Buying Behaviour & 0.685 & 0.669
\end{tabular}

Table 9

The decision criteria of $\mathrm{R} 2$ must be $<0.6$ but here we are having the value of $R^{2} 0.68$ which is significant, and the impact of independent variable is strongly effecting the dependent variable. The results are indicating that the dependent variable consumer buying behaviour is influenced by the independent variables free sample offers, free coupon offers, price reductions and buy one get one free offers. The research is significant and appropriate. 


\section{CONCLUSION}

Today corporations or business organizations spend an extensive amount of the budget on sales promotion activities. The main idea behind offering such promotion activities is to make the goods more appealing and valuable to the customers. The organization intends to alter consumers' buying behavior and persuasive towards the purchase of the product or service which they are offering. The purpose of this study is to find the impact of various promotional tools on consumer buying behavior although various studies have measured the impact of promotional tools but the study discusses the impact of free samples, price reduction, coupon, buy one get one free \& consumer buying behavior. We are taking the retail sector (FMCG or other) to conduct the research. The Business environment has gotten to be exceptionally competitive within the 21 st century due to the speed of mechanical alter, framework, and get to access the data around the globe. This has made the environment exceptionally complex and shopper inclinations keep changing since of the low exchanging fetched within the market. Due to this expanding request of consumers within the showcase, the administration of organizations ought to increment their consideration on attracting and holding its customers. Promotional tools plays an important role among shoppers, retailers, manufacturers and, marketers. Through promotional tools manufacturers, retailers, marketers generates more revenue and sales will be increased. Many retailers, manufacturers, retailers, marketers attract the customers by using different promotional tools. This study is performed in Karachi, Sindh, Pakistan to perceive the behavior of consumers related to different promotional tools. The primary data is collected through structured questionnaire which was adapted from several related researches. The respondents include both female and male and the sample size is 208 get hold to collect the primary data for the research. According to demographics most respondents are between 18 to 25 years old and the young in age responses are been focused. Most respondent's income level is below 15000 Rupees that means the people of Karachi, Sindh, Pakistan lays on middle class range and on the basis of poverty level, below 15000 income level has been focused. The research's mostly respondent's qualification is bachelors so, the research focuses on educated audience. Also, the study shows that the talked about promotional tools plays an important role on consumer buying behavior. Our studies found that the impact of independent variables on dependent variable is strong. impact of B1G1 and free sample offers are not reliable and impact of free samples and price reduction are reliable on consumer buying behavior so, the companies, marketers, manufacturers and, retailers give 
more focus on providing free samples and price reduction at the time of promotions. Hence, the more investing on free samples and price reduction can give more profit.

As such, the results of this research confirms that promotional tools like free sample offers and price reduction plays a key on the impacting of consumer buying behavior and the shoppers are more attracted towards free sample offers and price reductions on the products which they have interest to buy the products or stimulated to buy the products.

\section{RECOMMENDATIONS}

In order to impact the consumer buying behavior effectively. The recommendations have been made to improve the practices of different promotional tools. The following things may be noticeable. Buy on get one free offer, free sample offers, free coupon offers, price reductions can deduct the profitability so the offers should put in carefully. The effect of different promotional tools is short term. By giving services a service provider can maintain the long term relationship with customer or consumer by satisfying the their needs. Service provider must continually attach with related buying behavior researches to reduce the complains of customers. Promotional tools stimulates the customers to buy more so the promotional should use on the continues basis but in care full way. Service provider should invest different promotional tools but in an effective manner. To attract more customers service provider should organize the different promotional tools on the basis of customer needs. Continually giving promotions can affect the brand image, equity of a brand and customer loyalty. Due to shortage of time and resources the sample size is short, the sample size should increase in an effective manner. This study focuses some of the promotional tools so in some manner many different promotional should be focused in impact on promotional tools. Research should focuses on different culture's people, income level, people's qualification and their professions while they are on jobs or on off-jobs. The researcher should visit the places where the business transactions occurs. That thing will help the researcher for taking the relevant information regarding the consumer buying behavior. Also, the place plays an important role to attract the customers. The service provider must promote their products at the right time, at the right place, to the right audience. The service provider more focus on giving free samples and price reduction rather than $\mathrm{B} 1 \mathrm{G} 1$ and free coupons and more invest in giving free samples and price reduction of the products for to gain more profit. 


\section{REFERENCES}

Abdi, A. S. (2015). Sales Promotion Tools on Consumer Buying Behavior: A Case Of Shopping Centre In Mogadishu, Somalia (Doctoral Dissertation, Lincoln University College).

Abebe, R. (2020). Effect of Sales Promotion on Consumer Buying Behaviour: In Case Of CocaCola Soft Drink, Bahir Dar City (Doctoral Dissertation).

Ahmad, S. A., Mehmood, W., Ahmed, S. A., Mustafa, M., Khan, M. F. T., \& Yasmeen, M. (2015). Impact of Sales Promotion on consumer buying behavior in Pakistan. International Interdisciplinary Journal of Scholarly Research, 1(3), 13-22.

Ahmed, N. The Impact of Sales Promotion on Consumer Buying Behavior.

Ashraf, M. G., Rizwan, M., Iqbal, A., \& Khan, M. A. (2014). The promotional tools and situational factors impact consumer buying behavior and sales promotion. Journal of Public Administration and Governance, 4(2), 179-201.

Imtiaz, A., Maqsood, S., Mehmood, M. F., \& Idrees, M. Assessing the Effects of Promotional Tools on Consumer Buying Behavior in Faisalabad.

Ismail, A., \& Siddiqui, D. A. (2019). Impact of sales promotion on consumer impulse purchases in Karachi, Pakistan. Pakistan (May 7, 2019).

Khan, M., Tanveer, A., \& Zubair, D. S. S. (2019). Impact of Sales Promotion on Consumer Buying Behavior: A Case of Modern Trade, Pakistan. Impact of sales promotion on consumer buying behavior: a case of modern trade, Pakistan. Governance and Management Review, 4(1), 38-53.

Malombeke, S., Saerang, D. P. E., \& Pangemanan, S. S. (2014). The Impact of Promotional Tools on Consumer Buying Behavior at Matahari Department Store Manado Town Square. Jurnal EMBA: Jurnal Riset Ekonomi, Manajemen, Bisnis dan Akuntansi, 2(1).

Meo, A., Abbas, M. D., Sajjad, M. N., Rizwan, M., \& Hameed, M. S. (2014). The impact of promotional tools on sales promotion. Journal of public administration and governance, 4(2), 202-216.

Morse, J. (2016). Mixed method design: Principles and procedures. Routledge. 
Mughal, A., Mehmood, A., Mohiuddeen, A., \& Ahmad, B. (2014). The impact of promotional tools on consumer buying behavior: a study from Pakistan. Journal of Public Administration and Governance, 4(3), 402-414.

Muhammad, D. (2012). SALES PROMOTION AND CONSUMER BUYING DECISIONS: A CASE STUDY OF SOME SELECTED LOCAL GOVERNMENT IN ZONE A. OF NIGER STATE.

Nasir, S., \& Bal, E. (2016). Sales promotional strategies and buying behavior in an emerging market in the post-recession period. In Handbook of Research on Consumerism and Buying Behavior in Developing Nations (pp. 239-262). IGI Global.

Rasool, A. B., \& Mahmood, M. A. (2018). The Effects of Sales Promotion on Customer Buying Behavior An Analytical study on Carrefour supermarket's customers in Erbil. Zanco Journal of Humanity Sciences, 22(1), 297-315.

Shamout, M. D. (2016). The impact of promotional tools on consumer buying behavior in the retail market. International Journal of Business and Social Science, 7(1), 75-85. 